\title{
Reconciliation Discourse of 1965 and Indonesian ness Reconstruction In the Post-New Order
}

\author{
St.Tri Guntur Narwaya ${ }^{1}$, Faruk HT $^{2}$, Budiawan ${ }^{3}$ \\ Universitas Mercu Buana Yogyakarta ${ }^{1}$, Universitas Gadjah Mada ${ }^{2-3}$ \\ gunturnarwaya@yahoo.com¹, farukfaruk767@gmail.com², bwan4@yahoo.com³
}

\begin{abstract}
This paper examines how the practice of articulation, negotiation and the contest of reconciliation discourse of 1965 influenced and was influenced by various other discursive formations, especially by the moments of the construction of "Indonesian-ness" in the post New Order' era. This study focuses on discourse analysis approach in a Post-Structural perspective developed by Ernesto Laclau and Chantal Mouffe. This study found important points: First, the discourse of reconciliation itself is not a discourse which is immune to various developing contest and negotiations. It's also influenced by the tug of war of other various discourses. Second, in practice, every hegemony to interpret the reconciliation formula of 1965 is always challenged by various other competing discourses. Third, the various negotiations and contests of reconciliation cannot be separated from the relationship with the tug of war of negotiations and contest on how Indonesian-ness construction is formed, formulated and contested by various parties.
\end{abstract}

Keywords: 1965 Reconciliation, Post-Structuralist, Negotiations, Ernesto Laclau Discourse Analysis, Indonesian-ness

\section{Introduction}

The political violence of 1965 - 1966 had a serious impact, not only in the direction of the changes of social, economic and political structures, but also in the landscape of changes in Indonesia's political construction in the following years. The moment of negative experience (negativity), singularly contributes to the construction of the subject identity of society as well as the nation [1][2][3]. Examining the articulation of reconciliation, it is quite helpful to understand changes in the construction of Indonesian-ness discourse which is being and continues to be negotiated [4].

After the fall of Soeharto, many ideas of democratization emerged in various fields which at the same time became a means to minimize the potential for a wretched historical return. Various pioneering ideas about 'national reconciliation' and disclosure of the past human rights violations began to emerge. In the initial embryo, the idea of national reconciliation seems to be overlap with other various articulations simultaneously emerge, such as the ideas of 'national consensus', 'national dialogue', 'national consultation', or other alternative proposal such as 'national Islah'. The reconciliation discourse is forced to compete and contest with various other developing discourse. The 1965 reconciliation discourse really has never been immune to various formations and articulations of discourse which dynamically interact with each other [5]. The focus of this paper is to show that there are a variety of argumentative 
texts, narrative structures, the dynamics of the discourse of reconciliation, which are in fact related to crucial moments of how Indonesian-ness images are reinterpreted and interpreted.

\section{Method}

This research applies a critical discourse analysis approach contributed by Ernesto Laclau and Chantal Mouffe's perspectives. The object of this study is the entire articulation of the narratives arise in the discussion and debate of the 1965 reconciliation discourse. Laclau's discourse analysis focusing on examining the dimensions of discourse articulation which are not limited to verbal texts, but of that which are in the context of broader social dimensions. In the perspective of Laclau and Mouffe, all social practices are regarded as discourse.

Discourse has been always present in its unique (specific) [6] formulation and articulation and always intersects with the domains of other plural contexts of discourse which configure it. The discourse in Laclau \& Mouffe's view is understood as a determination of meaning in a particular domain [7]. Each discourse in Laclau's basic view is a totality where each sign is designated as a 'moment' through its relation to other signs (as illustrated in the fishing nets) $[8]$.

\section{Result and Discussion}

\subsection{Understanding Indonesian-ness in the Post-New Order Era}

Indonesian-ness which is being constructed in the Post New Order is Indonesian-ness which is free from contact and influence of its ideological enemy, 'communism'. The New Order formulated a political consensus by interpreting the past (the Old Order era) and defining a different position from the practice of that past articulation. The meaning of the 'New Order' relates to an understanding of the great narrative of anti-communist [9]. The presence of fear of the emergence of bad events like those which have occurred in the past, is often used by the regime to control fear as well as mastering the psychology and mass memory [10]. The narrative pledge on "the implementation of Pancasila and the 1945 Constitution in a pure and consistent manner" [11] refers to the interpretation that the past (the Old Order) has proven to have misused and wrong efforts in carrying out the life of the nation and the state. One which is quite important and becomes the center of indoctrination of the nationhood institutionalization, is the credo of the implementation of Pancasila as the only national value of identity [12].

The transition period to the fall of Soeharto was an important crossing point of reading the situation of 'continuity' and "disconnection" (discontinuity) of the various developments of discourse. The impact of various pressures for change in the reform era and especially the successful political steps of the 1945 amendment in 1999, at least have drowned out the grand narrative of the consensus on the implementation of Pancasila and the 1945 Constitution in a pure and consistent manner, although on a limited scale, the discourse to push back to the application of the 1945 Constitution, as done before the amendment, several times were voiced by several parties and especially by high-ranking former Indonesian military officials. 
The discourse of returning to the former implementation of the 1945 Constitution actually reflects the desire of the military to be able to re-enter civil affairs. The discourse was no more than an articulation for the consolidation of power after the Reformation. With the decision to revoke the dual functions of ABRI, the military was forced to be kept away from practical political involvement. However, it must also be recognized, that the consolidation of military power seems to be getting stronger after the reformations are underway. Vedi R. Hadiz gave an important note on this matter that, even though developments that later occurred showed that the military was withdrawing, this institution remained strong enough to ensure that its institutional interests would not be ignored by the civilian elite and that they even continued to have significant influence at the national and local level [13].

\subsection{The 1965 Reconciliation in Indonesian-ness Preference and Negotiations}

In the initial idea concerning the development of the reconciliation discourse, national preferences have always been the basis for considerations. Even just to make consensus on the formulation and definition of the names, many parties must agree on the choice of the phrase 'national' to meaningfully emphasize that the idea of reconciliation is an effort which cannot be separated from how national consensus can be realized to solve the problems of the nation. The national reconciliation effort is directed to address the issue of concern on the emergence of national disintegration. Reconciliation can also be interpreted as a way to overcome the crisis in the form of conflict and tension occurred in the post-New Order transition period. Some traces of that idea can be found in the idea of establishing an institution of KKR.

The success of laying the frame of interest in the doctrine of 'unity and integrity' definitively appears in the final results of the formulation of the KKR Law. In the points of consideration and in the chapter on General Provisions especially the understanding of what is meant by 'reconciliation', the KKR Law clearly states the basis for the discourse. Chapter I, Article 1 point 2 of the KKR Law states (RI Law No. 27 of 2004 concerning the Truth and Reconciliation Commission - This law was finally canceled by the Court) that: Reconciliation is the result of a process of disclosing the truth, recognition and forgiveness, through the Truth and Reconciliation Commission in the context of resolving gross human rights violations for the creation of peace and national unity".The first and second points of the explanation given by the government to set the TRC Law into the previous law, also explicitly explained that the formation of a TRC cannot be separated from the fundamental interests for 'national unity and integrity' [14].

It cannot be denied that this discourse reinforces the principle that desirable Indonesianness is a harmonious, peaceful one and Indonesian-ness which minimizes conflict. The formulas listed in the General Provisions Chapter of RI Law No. 27 of 2004 concerning the TRC (before being canceled by the Constitutional Court) stated definitively the concept of Reconciliation which is related to the Indonesian-ness image which upholds national unity. The law stated that "Reconciliation is the result of a process of disclosing the truth, recognition and forgiveness, through the Truth and Reconciliation Commission in the context of resolving gross human rights violations for the creation of peace and national unity." Due to the absence of a more complete explanation of the meaning of peace and national unity, the principle is ultimately still very loose and fluid.

The discourse on the Indonesian-ness, then becomes very flexible and slippery to be drawn in any direction. In different articulations, each of the supporters and opponents of the idea of reconciliation can use the same preferences. The two quotes of views below can help to understand what is meant. The author takes excerpts from As'id Said Ali as PBNU's board 
member in the 'Iktitam' of "The Clash of NU-PKI 1948-1965" and compares it with the opening notes of "Rediscovering Indonesia" written by KKPK.

"In the course of this nation, we have gone the wrong way. We take the shortcut of violence and finally disappear in the middle of the jungle of impunity. We move away from the direction and ideals of the constitution. We are no longer loyal to the initial idea of reformation. The 40-year experience of this nation shows that thousands and even millions of Indonesian citizens actually plummet into the vortex of injustice and seem to have no room and hope to rediscover their dreams about Indonesia. Now the time has come to find Indonesia again, Indonesia as aspired by the founding fathers, a prosperous Indonesian nation, an Indonesia which respects, an Indonesia which protects, and Indonesia which guarantees the constitutional rights of all its citizens" " [15]

"Indonesia is a large nation which has a very rich cultural heritage. Actually, this nation has its own mechanism to resolve the crisis at hand. Therefore, outside interference, even foreign pressure, such as that carried out by Amnesty International or the International Court of Justice and other international institutions in resolving the 1965 incident will distort the reconciliation process that has occurred so far" [16].

Quotations taken from the narrative of the Coalition for Justice and Truth (KKPK), tend to see the 'Indonesian-ness' today as Indonesia which has gone astray. Indonesia depicted in its old ideals has been distorted. The 40-year reflection on the nation's journey shows that what had been conceived and imagined by the nation's founders was in fact misunderstood. Indonesia is still held hostage by many problems in the form of various practices of political violence destroying the values of welfare, justice, protection and constitutional guarantees for all citizens. The preference of Indonesian-ness has become a fundamental spirit for the path of truth-telling and reconciliation. Breaking the chain of impunity becomes an urgent work.

As'ad Said Ali's excerpts actually understand Indonesia as a large nation which is strong and at the same time not easily intervened with what is considered to be the interests of a foreign country. The notes were submitted to respond to the involvement of several international institutions such as Amnesty International and the International Court of Justice in Den Haag which were involved to encourage the truth-telling process. Indonesia is considered to have a model and mechanism to complete the agenda of disclosing the truth of the past without the intervention of foreign parties or institutions funded by foreigners.

Allergic and suspicious attitudes towards foreign involvement can actually be read as ambiguous attitudes which are often shown by the New Order reasoning. Since its establishment, in practice, the New Order had established relations with foreign parties, but at the same time, at a certain moment, it still constructs a discourse on independence and sovereignty. This principle is similar to the attitude of the New Order in understanding Democracy and Human Rights as something considered as a value coming from outside (western) which is secular, individualistic, liberal and not nationalist. This view is still relatively persistent, just as the concepts of consensus and harmony which are considered to be the original values of the Indonesian nation and thus this view always rejects and even denounces the opposition and conflict which are always regarded as products of individualistic Western [17]

But there are also many discourses which actually lay a very strong relationship between aspects of national unity and the need for respect and justice for the victims. The meaning of unity is not understood as a discourse on binding control, but rather must be understood in the 
spirit of unity with solidarity and empathy for the victims of human rights violations. Therefore, the development of the one Indonesia also presupposes a process of reconciliation with the victims, because without acknowledgment of the authority of the suffering of the victims, the morality which is the basis of shared life becomes fragile and meaningless [18]. A nation built on this kind of morality will also not be able to unite in peace on its history full of wounds and violence. National unity requires a solidarity with the victims. The glorification of the value of 'harmonization' has a reference which can be explored and traced from the time when the ideas and concept of 'integral state' were developed as a political doctrine for the organic state of the New Order.

The second trace of discourse which can be seen from the perspective of the integration and harmonization of this nation is the relation of its influence with one of the trends in reconciliation choices which offer more 'integrative impunity' as a way out. This 'integrativeimpunity' tendency considers that for the sake of good national unity, it is not important to always dig up secrets of and blame the past. Wisdom is needed to be able to forgive everything which has passed. The more practical ideas, encourage the process of impunity (forgiveness) for the perpetrators. Phrases such as "this nation is not a vengeful nation" and "this nation is a forgiving nation", "NKRI is a fixed price" and "a nation which can always solve problems with good deliberation", has emphasized the way that the mechanism of reconciliation and disclosure of the truth of the past through a human rights court will only add new wounds and will create a crisis and a revenge cycle which will simultaneously threaten crises, conflicts and national integration.

The third track, the idea of reconciliation, especially carried by some parties who refuse it explicitly or accept it with certain conditions, is not much different from the idea of how to define the subject of Indonesian-ness. Such Indonesian-ness identity in many ways explains who is allowed to enter the reconciliation idea and who is not allowed to be involved in determining reconciliation ideas. This is related to the tendency of anti-communist discourse which participate in negotiating the formulations of reconciliation. The last view, read by the TNI / Polri Faction shows this tendency.

"The decisions of the Truth and Reconciliation Commission are not used as media to justify a Makar crime against the Republic of Indonesia, because besides of being contrary to the principle of truth, also in the future it will not be used as a reason for a repeating of the betrayal of the nation. Against all incidents of gross human rights violations occurred before the enactment of Law no. 26 of 2000 concerning Human Rights Courts but which cannot yet be resolved by the TRC is possible to be resolved through an ad hoc human rights court based on applicable law" [19].

The rejection by using the excuse of concern that 'communist' elements will influence the course of the formulation of reconciliation is constantly voiced and at the same time they want to assert that the Indonesian-ness identity expected by the old interest parties is an Indonesia which is free from the communist influence. This tendency to strengthen the 'anti-communist' sentiment in many ways is one of the obstacles to the process of reconciliation (Budiawan, 2004). Of course, this view is contrary to the discourse of reconciliation put forward by human rights activists or by most of the victims / survivors' community which emphasizes the dimension of justice and human rights enforcement rather than the principle of "impunity integration" which is often illusory and tends to defend the interests of perpetrators of human rights crimes. 
The fourth trace is reflected in the resistance of some parties' rejection of various discourse proposals considered not to come from Indonesian culture. The idea of reconciliation was considered not to represent the wisdom of Indonesian culture and is considered unsuitable to be a mechanism for solving problems in the past. The notion of human rights (HAM) is even considered to be an idea represents western interests which is clearly incompatible and will only disrupt the nation's political stability. Another similar opinion also considers that issue of democracy and human rights are only the mode of tactics and efforts of the initiators to change the state ideology and provide space for the revival of communist ideology in Indonesia.

On a number of occasions, the idea of Indonesian-ness was then used by those who were committed to working for the reconciliation of the 1965 tragedy. In contrast to their articulation practices which narrow the understanding of Indonesian-ness only as the value of national unity and integrity, Indonesian-ness is actually interpreted as a shared space that must be continually filled with values of justice and respect for humanity. Indonesia in the period of violence and impunity, according to the KKPK is the wrong Indonesia and not in accordance with what was imagined by the founders of the nation. Indonesian-ness is then dreamed of as a good space, for the fulfillment of prosperity, respect and for ensuring the rights of every citizen protected by the constitution. This is clearly different from the Indonesian imagination which is often read in the perspective of power. Salahudin Wahid, who at that time was a commissioner of the National Human Rights Commission also emphasized the national aspect to interpret the function of reconciliation. According to his account, the Indonesian people must be able to get out of the wounds of the past and become a healthy nation through reconciliation and rejecting impunity [20].

Salahudin Wahid's critical note emphasizes the importance of revealing the truth of the past to be a part of how to heal the wounds of the past. A similar expression was given by Wole Sayinka, 1986 Nobel Prize winner in Nigerian Literature that "by recognizing the past crimes, a nation can move more lightly into the future" [21]. In another understanding, the courage to face and read the past history correctly, will be a valuable capital for the future journey of the nation. The Indonesian-ness image of the future is closely related to our view of the past. An important correlation between the reconciliation function and the formation of the Indonesian-ness image of the future lies precisely at this fundamental point.

\section{Conclusions}

Some important concluding notes that can be found in the analysis of this paper are: First, since the very beginning of the emergence of the idea of reconciliation, it could not avoid the tug of various configurations of existing discourse. They fought over the hegemony of meaning of how 'reconciliation of 1965 ' had to be formulated and interpreted. Second, the preference and construction of Indonesian-ness values is one which is often referred to as an excuse among other different preferences such as religion, democracy and human rights (HAM). Indonesian-ness preferences focusing more on the characteristics of 'integrative' as reflecting on the meaning of 'national unity and integrity' are much articulated by the interests of old political forces, especially by the military in Indonesia. Third, integrative preferences are often used as an excuse for denying the responsibility that should have been done by them (perpetrators) in the past criminal cases. At other times, this 'integrative' argument has often been articulated to reject the proposal of holding a human rights court for perpetrators. Fourth, 
factually, the 'integrative impunity' discourse is still solid enough to be a hegemonic proposal for the 1965 reconciliation road map.

\section{References}

[1]. Anderson, B O'G. Language and Power, Exploring Political Cultural in Indonesia, Ithaca and London : Cornel University Press. pp. 119 (1990).

[2]. Lane, M. Unfinished Nation (Penerjemah: Danial Indrakusuma), Yogyakarta: Penerbit Djaman Baroe. pp. 430. (2014).

[3]. Hardiman, F. B. Memahami Negativitas: Diskursus tentang Massa, Teror dan Trauma. 2005. Jakarta: Penerbit Kompas. http://indoprogress.com/2012/09/wawancara-2/. pp. 177. Tanggal akses 18 Juli 2016

[4]. Roosa, J. Prof. John Roosa: Idenitas bangsa Indonesia berubah total sesudah 1965. https://indoprogress.com/2012/09/wawancara-2/ 2012. Tanggal akses 5 Mei 2018.

[5]. Jorgensen, M \& Phillips, L J.. Analisis Wacana: Teori dan Metode (Penerjemah: Imam Suyitno, dkk), Yoryakarta: Penerbit Pustaka Pelajar. pp. 45. (2010).

[6]. Barker, C. The Sage Dictionary of Cultural Studies, London: Sage Publications. Pp. 54. (2004)

[7]. Laclau, E \& Mouffe, C. Hegemony and Socialist Strategy: Towards a Radical Democratic Politics, London: Verso. pp.112. (2001).

[8]. Jorgensen, M \& Phillips, L J.. Analisis Wacana: Teori dan Metode (Penerjemah: Imam Suyitno, dkk), Yoryakarta: Penerbit Pustaka Pelajar. pp. 26. (2010).

[9]. Notosusanto, N. (ed). Tercapainya Konsensus Nasional 1966 - 1969, Jakarta: Penerbit Balai Pustaka.Republika, 7 September 1998. pp. 27. (1985).

[10]. Hardiman, F. B. Memahami Negativitas: Diskursus tentang Massa, Teror dan Trauma, Jakarta: Penerbit Kompas. http://indoprogress.com/2012/09/wawancara-2/2005. pp. 178. Tanggal akses 18 Juli 2016.

[11]. Silalahi, H. T. Konsensus Politik Nasional Orde Baru: Ortodoksi dan Aktualisasinya, Jakarta: Penerbit CSIS. pp.3. (1990).

[12]. Bertrand, J. Nasionalisme dan Konflik Etnis di Indonesia (Penerjemah: Achmad Munjid), Yogyakarta: Penerbit Ombak. Pp. 63-64 (2012).

[13]. Hadiz, V R. Dinamika Kekuasaan, Ekonomi Politik Indonesia Pasca-Soeharto, Jakarta: Penerbit LP3ES. Pp.217. (2005).

[14]. Danusubroto, S. Bicara dengan Sejarah dami Melalui Rekonsiliasi, Jakarta: Mulatazam Mitra Prima. pp. 21. (2005)

[15]. Laporan Tahun Kebenaran KKPK, Menemukan Kembali Indonesia: Memahami Empat Puluh Tahun Kekerasan Demi Memutus Rantai Impunitas, Jakarta. pp.v. ( 2014).

[16]. Ali, A. S. "NU Konsisten Menjaga Keutuhan Negara Ini”, dalam buku Abdul Mun;im DZ, Benturan NU - PKI 1948 - 1965, Jakarta: Penerbit Pengurus Besar Nahdatul Ulama (PBNU). pp.xvi. (2013).

[17]. Bourchier, D. Pancasila Versi Orde Baru dan Asal Muasal Negara Organis (Integralistik) (Penterjemah: Agus Wahyudi), Yogyakarta: Penerbit Aditya Media Yogyakarta bekerja sama dengan Pusat Studi Pancasila (PSP) UGM. pp.3. ( 2007).

[18]. Madung, O G. Post-Sekularisme, Toleransi dan Demokrasi, Flores: Penerbit Ledalero. pp.164. (2017).

[19]. Danusubroto, S. Bicara dengan Sejarah dami Melalui Rekonsiliasi, Jakarta: Mulatazam Mitra Prima. Pp.224. (2005).

[20]. Kompas, 3 March 2005.

[21]. Kompas, 26 September 2003. 